\title{
HUBUNGAN STOK KARBON TANAH DAN SUHU PERMUKAAN PADA BEBERAPA PENGGUNAAN LAHAN DI NAGARI PADANG LAWEH KABUPATEN SIJUNJUNG
}

\author{
Gunadi $^{*}$, Juniarti ${ }^{1}$, Gusnidar ${ }^{1}$ \\ ${ }^{1}$ Jurusan Ilmu Tanah Fakultas Pertanian Universitas Andalas \\ *Email: gun.adi1922@gmail.com
}

\begin{abstract}
The content of soil C-organic is strongly influenced by land management. Plants tend to increase soil organic C-stock, however an increase in soil temperature can increase the rate of decomposition of soil organic matter which will reduce soil organic C-stock. The aim of the study is to look at the relationship of soil organic carbon stock (SOCS) with changes in soil surface temperature. The study was conducted using a survey method consisting of 5 stages, namely preparation, pre-survey, main survey, soil analysis in the laboratory and data processing. Soil sampling is done by purposive random sampling under several land units (LU). LU is limited by the order of the soil, slope, and land use. Based on the land unit map, we found 14 land units in the study area. Soil samples were taken at a depth of 0-20 cm. Surface temperature measurements are carried out directly in the field using a room temperature thermometer. The parameters analyzed are organic- $\mathrm{C}$, organic particulate$\mathrm{C}$, and bulk density (BD). The research data were processed statistically using simple linear regression equations. The results showed that the measurement of rice field surface temperature had the highest temperature of $34{ }^{\circ} \mathrm{C}$, and rubber plantations had the lowest temperature of $28{ }^{0} \mathrm{C}$. Organic- $\mathrm{C}$ affects soil $\mathrm{BD}$, the higher the value of organic- $\mathrm{C}$, the lower the $\mathrm{BD}$ value. The highest carbon stock was found in soil unit 10 with rubber plantations with a slope of 8-15\%, $41 \mathrm{~kg} \mathrm{~m}-2$ and decreased with increasing slope. The difference in the value of SOCS in rice fields is influenced by land management, because there is no return of crops residue in the form of straw to the ground. The results of the regression analysis showed that surface temperature did not have a significant effect on the SOCS value.
\end{abstract}

Keywords : carbon stock, land use, Padang Laweh

(C) 2020 Gunadi, Juniarti, Gusnidar

\section{PENDAHULUAN}

Karbon organik tanah bersumber dari dekomposisi tanaman dan hewan. Karbon organik tanah merupakan komponen yang sangat penting di dalam usaha pertanian berkelanjutan. Nilai $\mathrm{C}$ organik tanah memegang peranan penting dalam meningkatkan karakteristik sifat fisika dan kimia tanah. Kadar $\mathrm{C}$ organik tanah menentukan kesuburan, produktivitas, dan kualitas tanah. Selain itu, perubahan sirkulasi C organik tanah akan berpengaruh terhadap siklus karbon dan perubahan iklim jangka panjang.
Perubahan kecil pada pool $\mathrm{C}$ organik tanah akan berdampak pada konsentrasi $\mathrm{CO}_{2}$ di atmosfer, sehingga berdampak kepada perubahan suhu permukaan, presipitasi, radiasi matahari, dan kecepatan angin. Pengaruh karbon tanah terhadap pemanasan global tergantung pada keseimbangan antara input karbon ke tanah dengan peningkatan produktivitas tanaman. Tanaman cenderung meningkatkan stok $\mathrm{C}$ organik tanah dan meningkatnya laju dekomposisi pada suhu yang lebih tinggi. Pada suhu tanah yang lebih tinggi akan menurunkan stok $\mathrm{C}$ organik tanah (Smith et al., 2008). Nilai C organik tanah, 
berubah dengan perubahan suhu, dan dapat menurun ketersediaannya dengan meningkatnya suhu (Qi et al., 2016).

Pada kondisi alami, C organik tanah berasal dari sisa tanaman, baik segar maupun yang telah terdekomposisi sempurna seperti humus. Ketersediaan $\mathrm{C}$ organik tanah dipengaruhi oleh manajemen lahan, seperti pengolahan tanah, perubahan penggunaan lahan, ada atau tidak adanya pengembalian sisa panen dan lain-lain. Hal ini menyebabkan hilangnya $\mathrm{C}$ organik tanah. Selain itu, ketersediaan $\mathrm{C}$ organik tanah juga dipengaruhi oleh jenis tanah, vegetasi, topografi, sejarah penggunaan lahan, dan iklim. Stok $C$ organik tanah dapat di tingkatkan dengan olah tanah minimum dan pemberian pupuk kompos (Krauss et al., 2017).

Dilihat dari pengelompokannya, maka karbon organik tanah dibagi menjadi fraksi labil ( $\mathrm{C}$ organik tanah partikulat), dan fraksi $\mathrm{C}$ organik stabil (bahan humat) (Strosser, 2010). Fraksi $\mathrm{C}$ organik tanah labil seperti $\mathrm{C}$ organik partikulat sangat sensitif terhadap perubahan penggunaan lahan dan merupakan indikator yang paling peka terhadap kualitas tanah. Sedangkan fraksi C organik stabil lebih resisten terhadap perubahan penggunaan lahan dan dapat digunakan sebagai indikator untuk menilai kapasitas tanah dalam menyimpan karbon (Ermadani et al., 2018).

Fraksi C organik partikulat merupakan fraksi karbon yang sangat labil yang keberadaannya sangat dipengaruhi oleh penggunaan lahan. Nilai $\mathrm{C}$ organik partikulat lebih banyak ditemukan pada padang rumput dibandingkan di lahan tanaman pangan, dan akan menurun apabila terjadi konversi dari padang rumput menjadi lahan tanaman pangan (Chan, 2001).

Perubahan penggunaan lahan berdampak kepada iklim lokal. Hal ini menyebabkan terjadinya perbedaan suhu permukaan yang berbeda pada setiap penggunaan lahan. Penurunan jumlah vegetasi dan adanya perusakan tutupan lahan alami akan meningkatkan suhu permukaan tanah pada berbagai kelas penggunaan lahan. Peningkatan suhu dapat dikaitkan dengan pola budidaya yang berbeda (Fathizad et al., 2017).

Nagari Padang Laweh terletak di kecamatan Koto VII Kabupaten Sijunjung Provinsi Sumatera Barat yang memiliki luas $1.569,92$ ha. Penggunaan lahan pada daerah ini di dominasi sawah, perkebunan rakyat, tanaman palawija, dan kebun campuran (BPS Kabupaten Sijunjung, 2017). Perbedaan penggunaan lahan menyebabkan sumbangan bahan organik ke dalam tanah berbeda. Selain itu, tidak adanya pengembalian sisa panen ke lahan sawah menyebabkan rendahnya bahan organik tanah. Tujuan penelitian ini adalah untuk mengetahui pengaruh suhu permukaan terhadap stok karbon tanah.

\section{BAHAN DAN METODA}

Penelitian dilaksanakan pada bulan Desember 2018 - Maret 2019. Bertempat di Nagari Padang Laweh, Kecamatan Koto VII, Kabupaten Sijunjung, Provinsi Sumatera Barat. Analisis sampel tanah dilakukan di Laboratorium Jurusan Tanah Fakultas Pertanian Universitas Andalas Padang.

Penelitian dilakukan menggunakan metode survei yang terdiri dari 5 tahap yaitu persiapan, prasurvei, survei utama, analisis tanah di laboratorium dan pengolahan data. tahap persiapan berguna untuk mengumpulkan data sekunder yang meliputi peta administrasi, peta lereng, peta tanah, dan peta penggunaan lahan. Tahap pra survei dilakukan untuk melakukan pengamatan kondisi fisik lahan dan penentuan titik pengambilan sampel tanah. Tahap survei utama untuk verifikasi hasil interpretasi satuan lahan dan pengambilan sampel tanah. Teknik pengambilan sampel tanah dilakukan secara purposive dengan pengambilan sampel secara random sampling berdasarkan satuan lahan dengan cara pemboran pada kedalaman 0-20 $\mathrm{cm}$. Berdasarkan peta satuan lahan, terdapat 14 satuan lahan. Pengukuran suhu permukaan tanah dilakukan secara langsung di lapangan menggunakan alat termometer suhu ruang, 
dengan cara termometer diletakkan di atas permukaan tanah bekas pengambilan sampel tanah dan ditunggu selama 10 menit. Pengukuran suhu permukaan tanah dilakukan sebanyak 3 kali untuk masing-masing satuan lahan. Pengukuran dilakukan pada siang hari mulai pukul 10.00 - 15.00 WIB.

Parameter yang diamati meliputi suhu permukaan tanah dan sifat kimia tanah. Pengukuran suhu permukaan dilakukan menggunakan termometer pada tiap satuan lahan. Sifat kimia tanah yang diuji terdiri dari C-organik, C-organik partikulat, dan BV.

Data hasil penelitian disajikan dalam bentuk tabel dan grafik. Perhitungan stok karbon tanah menggunakan persamaan menurut Yulnafatmawita dan Yasin (2018) yaitu:

$$
\mathrm{Ct}=\mathrm{BV} \times \mathrm{Kd} \times \% \mathrm{C} \text {-organik }
$$

Keterangan:

$\mathrm{Ct}=$ Kandungan karbon tanah $\left(\mathrm{Kg} / \mathrm{m}^{2}\right)$

$\mathrm{BV}=$ Berat volume tanah $(\mathrm{gram} / \mathrm{cm} 3)$

Kd $\quad=$ Kedalaman sampel tanah (cm)

$\% \mathrm{C}$-organik = Nilai persentase kandungan karbon organik tanah dari hasil pengukuran di laboratorium

Untuk mengetahui pengaruh suhu permukaan terhadap stok karbon tanah, maka data hasil pengukuran suhu permukaan dan perhitungan stok karbon diolah secara statistik menggunakan persamaan regresi linear sederhana. Sehingga persamaan regresinya yaitu:

$$
\mathrm{Y}=\mathrm{a}+\mathrm{bX}
$$

Dimana:

$\mathrm{Y}=$ Variabel terikat, yaitu suhu permukaan

a = Nilai konstanta

$\mathrm{b}=$ Nilai koefisien regresi

$\mathrm{X}_{1}=$ Variabel bebas1, yaitu stok karbon tanah

\section{HASIL DAN PEMBAHASAN Karakteristik Lahan}

Gambaran tentang fisiografi daerah penelitian dapat dilihat berdasarkan peta satuan lahan dan tanah lembar Solok (0815) skala 1:25.000 yang dikeluarkan dari Pusat Penelitian Tanah dan Agroklimat tahun 1990 yang kemudian dilakukan pencocokan dengan pengamatan di lapangan sehingga diperoleh 3 satuan fisiografi yaitu; (a) pelembahan sempit antara dataran tinggi, (b) dataran, (c) pegunungan.

Terdapat 2 jenis tanah pada tingkat Great Group yaitu; (a) Paleudults yang terdapat pada fisiografi dataran dan pegunungan dengan luas 910,29 ha, dan (b) Dystropepts yang terdapat pada fisiografi pelembahan sempit antara dataran tinggi dengan luas 659,63 ha.

Berdasarkan peta geologi lembar Solok (0815) skala 1:25.000 yang dipublikasikan oleh Pusat Penelitian dan Pengembangan Geologi tahun 1996 terdapat 2 jenis litologi yaitu; (a) Lempung dan napal abu-abu (dengan sisipan batupasir, konglomerat dan batupasir tufan berwarna kehijau-hijauan), dan (b) Batupasir kuarsa mengandung mika (pejal dan setempat mengalami malihan kuarsit). Tanah yang berasal dari bahan induk berupa batu pasir di daerah beriklim basah, akan mempunyai kejenuhan basa rendah, unsur hara rendah, dan $\mathrm{pH}$ tanah rendah (Puturuhu, 2015).

\section{Penggunaan Lahan}

Berdasarkan hasil analisis citra Landsat 7-ETM yang diambil pada tanggal 9 Oktober 2016, daerah penelitian memiliki 4 macam penggunaan lahan, yaitu pemukiman dengan luas 10,67 ha; kebun campuran dengan luas 941,45 ha; sawah dengan luas 361,60 ha; dan kebun karet dengan luas 256,20 ha (Gambar 1). Kebun campuran pada daerah penelitian merupakan lahan yang berada disekitar pemukiman yang ditanami dengan tanaman karet (Heveabraziliensis) yang ditumpangsarikan dengan berbagai macam tanaman tahunan, seperti kakao (Theobromacacao), kelapa (Cocos nucifera), kulit manis (Cinnamomum verum), pinang 
(Areca catechu), dan lansek (Lansium domesticum). Pada kebun campuran tidak ada pemberian pupuk kimia buatan, sehingga sumber unsur hara tanahnya berasal dari serasah dan sisa tanaman yang melapuk.

Pada kebun karet tidak dilakukan pemupukan, karena menurut petani tanaman karet akan tetap menghasilkan walaupun tidak diberi pupuk. Pembersihan gulma sangat jarang dilakukan, dan jika gulma sudah tinggi maka akan dilakukan pembersihan gulma menggunakan herbisida seperti roundup, Gramoxone, Gramakuat, dan lain-lain. Alasan penggunaan herbisida untuk pengendalian gulma adalah karena lebih praktis dan menghemat waktu.

Lahan sawah pada daerah penelitian didominasi oleh sawah tadah hujan dengan luas 183 ha, sedangkan sawah irigasi sebanyak 178 ha (BPS, 2018). Pengolahan tanah sawah dilakukan secara mekanis menggunakan handtractor dan secara manual menggunakan cangkul. Sisa panen berupa jerami dikumpulkan pada satu tempat di lahan kemudian dibakar sehingga menjadi abu. Pada lahan sawah tidak dilakukan rotasi tanaman baik itu pada sawah irigasi maupun sawah tadah hujan. Pada lahan sawah tadah hujan, saat musim kemarau dibiarkan hingga ditumbuhi rumput. Pemberian pupuk berbedabeda setiap petani karena petani tidak memiliki pedoman pemberian dosis pupuk. Pada umumnya pemberian pupuk dilakukan sebanyak 3 kali pada setiap musim tanam, yaitu tahap pertama pada saat tanaman padi berumur 2 minggu dipupuk Urea $100 \mathrm{~kg} / \mathrm{ha}$ dan TSP 50 $\mathrm{kg} / \mathrm{ha}$, pemberian pupuk tahap kedua dilakukan pada saat padi berumur 25-30 hari menggunakan pupuk Urea $50 \mathrm{~kg} / \mathrm{ha}$ dan Phonska $100 \mathrm{~kg} / \mathrm{ha}$, dan pemupukan tahap ketiga dilakukan pada saat padi berumur 40-45 hari menggunakan pupuk Urea sebanyak 50 $\mathrm{kg} / \mathrm{ha}$.

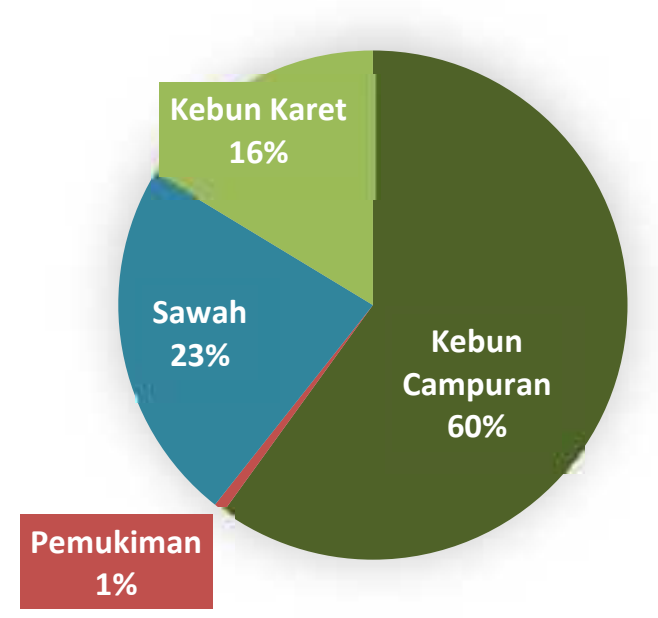

Gambar 1. Diagram penggunaan lahan di Nagari Padang Laweh

\section{Suhu Permukaan tanah}

Berdasarkan hasil pengukuran suhu permukaan di lapangan (Tabel 1), didapatkan bahwa lahan sawah memiliki suhu yang paling tinggi yaitu $34{ }^{\circ} \mathrm{C}$ pada satuan lahan 7 , dan kebun karet memiliki suhu paling rendah yaitu $28{ }^{\circ} \mathrm{C}$ pada satuan lahan 13 . Hal ini disebabkan karena pengambilan sampel tanah lahan sawah dilakukan setelah panen sehingga tidak ada tanaman penutup tanah yang menyebabkan radiasi matahari akan langsung mencapai permukaan tanah. Menurut Qin dan karneili (1999), pada tanah dengan vegetasi yang jarang, suhu permukaan ditentukan oleh suhu kanopi, tubuh vegetasi, dan permukaan tanah. 
Penggunaan lahan karet memiliki suhu permukaan antara 28-31 ${ }^{\circ} \mathrm{C}$ karena rapatnya vegetasi karet yang dipengaruhi oleh kerapatan tanaman karet yang mencapai 500-600 pohon/hektar dengan jarak tanam karet $4 \times 5$ meter dan 3x6 meter sehingga kanopi karet dapat menutupi permukaan tanah dari pancaran radiasi matahari secara langsung. Selain itu serasah dari tanaman karet yang jatuh akan menutupi permukaan tanah sehingga menyebabkan iklim mikro pada lahan karet menjadi lebih sejuk.

Kebun campuran memiliki suhu permukaan antara $30-32{ }^{\circ} \mathrm{C}$ dan sedikit lebih tinggi dibandingkan tanaman karet. Hal ini disebabkan karena pada kebun campuran tutupan vegetasinya tidak serapat pada tanaman karet karena pada kebun campuran terdiri dari berbagai jenis tanaman dan jarak tanam yang tidak teratur menyebabkan kanopi tanaman tidak terlalu rapat sehingga sebagian radiasi matahari sampai ke permukaan tanah.

Satuan lahan 13 memiliki suhu permukaan tanah $28{ }^{\circ} \mathrm{C}$ dan kandungan BOT $1,71 \%$. Hal ini disebabkan karena terdapat pada lereng curam sehingga bahan organik akan terbawa oleh aliran permukaan tanah. Pada lahan sawah dengan suhu $34{ }^{\circ} \mathrm{C}$ memiliki kandungan bahan organik $3,31 \%$ pada satuan lahan 5 dan $1,75 \%$ pada satuan lahan 7 . perbedaan kandungan bahan organik tanah disebabkan oleh manajemen lahan yang dilakukan oleh petani dengan tidak adanya pengembalian sisa panen ke lahan akan menyebabkan rendahnya kandungan bahan organik tanah.

Tabel 1. Suhu permukaan tanah dan bahan organik tanah (BOT) di Nagari Padang Laweh

\begin{tabular}{llclccc}
\hline $\begin{array}{c}\text { No. } \\
\text { SL }\end{array}$ & $\begin{array}{c}\text { Ordo } \\
\text { Tanah }\end{array}$ & $\begin{array}{c}\text { Kelas } \\
\text { Lereng } \\
(\%)\end{array}$ & Penggunaan Lahan & $\begin{array}{c}\text { Suhu } \\
\text { Permukaan* } \\
\left({ }^{0} \mathrm{C}\right)\end{array}$ & $\begin{array}{c}\text { BOT } \\
(\%)\end{array}$ & $\begin{array}{c}\text { Ketinggian } \\
\text { Tempat } \\
(\mathrm{m} / \mathrm{dpl})\end{array}$ \\
\hline 1 & Inceptisols & $0-8$ & Kebun Campuran & 31 & 1.76 & 139 \\
2 & Inceptisols & $8-15$ & Kebun Campuran & 32 & 3.05 & 157 \\
3 & Ultisols & $8-15$ & Kebun Campuran & 30 & 3.33 & 194 \\
4 & Inceptisols & $8-15$ & Sawah & 33 & 3.39 & 184 \\
5 & Ultisols & $8-15$ & Sawah & 34 & 3.31 & 163 \\
6 & Ultisols & $0-8$ & Sawah & 32 & 2.41 & 176 \\
7 & Inceptisols & $0-8$ & Sawah & 34 & 1.75 & 170 \\
8 & Ultisols & $0-8$ & Kebun Campuran & 32 & 3.73 & 181 \\
9 & Inceptisols & $15-25$ & Kebun Campuran & 32 & 2.77 & 183 \\
10 & Inceptisols & $8-15$ & Kebun Karet & 31 & 4.29 & 188 \\
11 & Inceptisols & $15-25$ & Kebun Karet & 30 & 3.48 & 196 \\
12 & Inceptisols & $25-40$ & Kebun Karet & 30 & 2.11 & 169 \\
13 & Ultisols & $>40$ & Kebun Karet & 28 & 1.71 & 186 \\
14 & Inceptisols & $15-25$ & Sawah & 33 & 2.77 & 175 \\
\hline
\end{tabular}

Sumber: $*$ ) = Hasil pengukuran di lapangan

Pada umumnya kandungan bahan organik tanah di lokasi penelitian dipengaruhi oleh penggunaan lahan, kelerengan, dan curah hujan. Fluktuasi suhu permukaan dan tingginya curah hujan akan menyebabkan laju dekomposisi bahan organik berlangsung cepat.

Suhu Permukaan tanah dipengaruhi oleh berbagai parameter seperti radiasi matahari, sudut radiasi matahari, sifat permukaan, kadar air, tingkat kerapatan vegetasi, dan ketinggian tempat (Khandelwal et al., 2018). Suhu akan mempengaruhi cepat atau lambatnya proses pelapukan bahan organik tanah dan keberadaan mikroorganisme tanah. Menurut Hanafiah (2005) suhu optimum aktivitas biota tanah yang menguntungkan terjadi pada temperatur $18-30{ }^{\circ} \mathrm{C}$, sedangkan pada suhu di bawah $10{ }^{\circ} \mathrm{C}$ aktivitasnya sangat 
terbatas, dan pada temperatur di atas $40{ }^{\circ} \mathrm{C}$ mikroba akan menjadi inaktif.

\section{Bahan Organik Tanah dan Bahan organik Partikulat}

Hasil analisis sampel tanah di laboratorium (Tabel 2), menunjukkan bahwa kandungan bahan organik tanah (BOT) di nagari Padang Laweh berkisar antara 1,71-4,29 $\%$. Lahan sawah memiliki kandungan BOT rendah. Hal ini disebabkan karena tidak adanya pengembalian sisa panen berupa jerami ke lahan karena jerami sisa panen di tumpuk pada satu tempat kemudian dibakar. Menurut Husnain (2010), pembakaran jerami menjadi abu akan mengakibatkan kehilangan unsur hara C $100 \%$, N 100\%, Si 35\%, K 47\%, P 59\%, Ca $44 \%, \mathrm{Mg} 42 \%$, Na $61 \%$ dari total kandungan unsur hara dalam jerami. Kehilangan hara tanah sawah disebabkan oleh scattering, sehingga partikel-partikel abu dan arang terbawa angin dan terhanyut oleh air hujan. Selain itu, tidak adanya penambahan bahan organik berupa pupuk kandang maupun kompos juga menyebabkan rendahnya kandungan C-organik tanah karena petani lebih cenderung untuk menggunakan pupuk buatan dalam memacu peningkatan produksi tanaman padi. Pengolahan lahan intensif dan penghilangan residu tanaman setelah panen menyebabkan penyimpanan $\mathrm{C}$ tanah yang rendah pada topsoil dan subsoil lahan pertanian (Kassa et al., 2010).

Kandungan BOT pada penggunaan lahan kebun campuran cukup tinggi, kecuali pada satuan lahan 1. Hal ini disebabkan karena curah hujan tinggi sehingga menyebabkan proses dekomposisi berlangsung cepat. Meningkatnya suhu dan curah hujan menyebabkan dekomposisi BOT lebih tinggi. Peningkatan suhu dan curah hujan terhadap C-organik tanah tergantung stabilitas C-organik dalam tanah (Guan et al., 2018).

Kandungan BOT pada penggunaan lahan kebun campuran cukup tinggi, kecuali pada satuan lahan 1. Hal ini disebabkan karena curah hujan tinggi sehingga menyebabkan proses dekomposisi berlangsung cepat. Meningkatnya suhu dan curah hujan menyebabkan dekomposisi BOT lebih tinggi. Peningkatan suhu dan curah hujan terhadap C-organik tanah tergantung stabilitas C-organik dalam tanah (Guan et al., 2018).

Pada satuan lahan 8, 10, dan 11 memiliki kandungan C-organik sedang. Hal ini disebabkan karena adanya tambahan bahan organik yang berasal dari serasah tanaman. Selain itu tingginya nisbah $\mathrm{C} / \mathrm{N}$ menandakan bahwa bahan organik masih berada pada awal pelapukan. Menurut Hanafiah (2005), apabila nisbah $\mathrm{C} / \mathrm{N}<20$ menunjukkan terjadinya mineralisasi $\mathrm{N}$, jika $>30 \%$ berarti terjadi immobilisasi (awal dekomposisi), sedangkan jika di antara 20-30 berarti mineralisasi dan immobilisasi berjalan seimbang. Kandungan Corganik tanah mengalami penurunan seiring dengan proses dekomposisi pada serasah daun karet (Iskandar, 2014).

Pada lahan sawah kandungan BOP berada pada kriteria sangat rendah hingga rendah. Hal ini disebabkan karena pada lahan sawah dilakukan pengolahan tanah intensif yang akan memecahkan agregat tanah, sehingga BOP akan keluar dan menjadi mudah terdekomposisi oleh mikroorganisme. Selain itu kandungan BOT yang rendah karena tidak adanya penambahan bahan organik dan pengangkutan sisa panen juga menjadi penyebab rendahnya kandungan BOP.

Pada penggunaan lahan kebun campuran dan kebun karet, kandungan BOP juga berada pada kriteria sangat rendah hingga rendah. Hal ini disebabkan karena rendahnya kandungan bahan organik tanah yang disebabkan karena curah hujan dan suhu yang tinggi yang akan mempercepat proses pelapukan pada bahan organik tanah. Peningkatan aktivitas biologis dan suhu menyebabkan peningkatan oksidasi fraksi C stabil dibandingkan fraksi labil, terutama pada tanah dengan kandungan $\mathrm{C}$ total rendah. Hal ini disebabkan karena adanya pemecahan fraksi stabil menjadi fraksi labil. Selama proses mineralisasi bahan organik tanah, bentuk yang kurang tahan atau labil dengan cepat diuraikan, diuapkan, atau dilepaskan yang mengakibatkan keberadaannya menjadi sedikit (Pires et al., 2017).

https://doi.org/10.25077/jsolum.17.1.1-11.2020 
Tabel 2. Hasil analisis C-organik, BOP, dan BV tanah di Nagari Padang Laweh

\begin{tabular}{llclcccrrr}
\hline $\begin{array}{c}\text { No. } \\
\text { SL }\end{array}$ & $\begin{array}{c}\text { Ordo } \\
\text { Tanah }\end{array}$ & $\begin{array}{c}\text { Kelas } \\
(\%)\end{array}$ & $\begin{array}{c}\text { Penggunaan } \\
\text { Lahan }\end{array}$ & $\begin{array}{c}\text { C-organik } \\
(\%)\end{array}$ & $\begin{array}{c}\text { BOT } \\
(\%)\end{array}$ & $\begin{array}{c}\text { BOP } \\
(\%)\end{array}$ & $\begin{array}{c}\text { BOP/BOT } \\
(\%)\end{array}$ & $\begin{array}{c}\text { BV } \\
\left(\mathrm{g} / \mathrm{cm}^{3}\right)\end{array}$ \\
\hline 1 & Inceptisols & $0-8$ & Kebun Campuran & $1.03 \mathrm{r}$ & 1.76 & $0.90 \mathrm{sr}$ & 50,99 & $0.92 \mathrm{~s}$ \\
2 & Inceptisols & $8-15$ & Kebun Campuran & $1.77 \mathrm{r}$ & 3.05 & 1.16 & $\mathrm{r}$ & 38,00 & $0.86 \mathrm{~s}$ \\
3 & Ultisols & $8-15$ & Kebun Campuran & $1.94 \mathrm{r}$ & 3.33 & 1.36 & $\mathrm{r}$ & 40,84 & $0.92 \mathrm{~s}$ \\
4 & Inceptisols & $8-15$ & Sawah & $1.97 \mathrm{r}$ & 3.39 & 1.34 & $\mathrm{r}$ & 39,58 & $0.87 \mathrm{~s}$ \\
5 & Ultisols & $8-15$ & Sawah & $1.92 \mathrm{r}$ & 3.31 & 1.89 & $\mathrm{r}$ & 57,11 & $0.90 \mathrm{~s}$ \\
6 & Ultisols & $0-8$ & Sawah & $1.40 \mathrm{r}$ & 2.41 & $0.76 \mathrm{sr}$ & 31,55 & $0.92 \mathrm{~s}$ \\
7 & Inceptisols & $0-8$ & Sawah & $1.02 \mathrm{r}$ & 1.75 & $0.56 \mathrm{sr}$ & 32,04 & $0.94 \mathrm{~s}$ \\
8 & Ultisols & $0-8$ & Kebun Campuran & $2.17 \mathrm{~s}$ & 3.73 & 1.64 & $\mathrm{r}$ & 43,94 & $0.90 \mathrm{~s}$ \\
9 & Inceptisols & $15-25$ & Kebun Campuran & $1.61 \mathrm{r}$ & 2.77 & $0.99 \mathrm{sr}$ & 35,72 & $0.91 \mathrm{~s}$ \\
10 & Inceptisols & $8-15$ & Kebun Karet & $2.49 \mathrm{~s}$ & 4.29 & 1.75 & $\mathrm{r}$ & 40,83 & $0.83 \mathrm{~s}$ \\
11 & Inceptisols & $15-25$ & Kebun Karet & $2.02 \mathrm{~s}$ & 3.48 & 1.34 & $\mathrm{r}$ & 38,48 & $0.89 \mathrm{~s}$ \\
12 & Inceptisols & $25-40$ & Kebun Karet & $1.23 \mathrm{r}$ & 2.11 & $0.19 \mathrm{sr}$ & 9,01 & $0.91 \mathrm{~s}$ \\
13 & Ultisols & $>40$ & Kebun Karet & $1.00 \mathrm{r}$ & 1.71 & $0.30 \mathrm{sr}$ & 17,50 & $1.05 \mathrm{~s}$ \\
14 & Inceptisols & $15-25$ & Sawah & $1.61 \mathrm{r}$ & 2.77 & 1.46 & $\mathrm{r}$ & 52,63 & $0.93 \mathrm{~s}$ \\
\hline
\end{tabular}

Keterangan: $\mathrm{sr}=$ sangat rendah, $\mathrm{r}=$ rendah, $\mathrm{s}=$ sedang (Balai Penelitian Tanah, 2012)

Nisbah BOP/BOT menunjukkan besar kecilnya fraksi bahan organik labil yang terlindungi dalam agregat tanah. Tingginya nilai BOP dan nisbah BOP/BOT menunjukkan bahwa fraksi bahan organik labil yang terlindungi dalam agregat tanah masih cukup banyak dan proporsinya terhadap C-organik total masih cukup banyak (Nurida et al., 2007). Pada satuan lahan 12 dan 13 memiliki nisbah BOP/BOT yang rendah. Hal ini disebabkan karena kandungan BOP berada pada kriteria rendah, sehingga fraksi bahan organik labil yang terlindungi dalam agregat tanah hanya sedikit. Selain itu, faktor lereng yang curam dan curah hujan yang tinggi mempengaruhi kandungan bahan organik tanah, karena setelah bahan organik melapuk menjadi fraksi labil akan terbawa oleh aliran permukaan sebelum bisa terlindungi oleh agregat tanah. Kehilangan $\mathrm{C}$ akibat pencucian dan erosi dapat mempengaruhi kandungan fraksi $\mathrm{C}$ organik labil pada berbagai penggunaan lahan. Karena pada umumnya bentuk Corganik labil memiliki tingkat kelarutan yang tinggi (Behtari et al., 2019).

\section{Berat Volume Tanah}

Berat volume tanah (BV) pada tiap satuan lahan diamati pada kedalaman $0-20 \mathrm{~cm}$. Berdasarkan Tabel 2, berat volume berkisar antara 0,83-1,05 $\mathrm{g} / \mathrm{cm}^{3}$ yang berada pada kriteria sedang. Hal ini disebabkan karena kandungan bahan organik yang rendah serta tekstur tanahnya yang didominasi oleh fraksi halus.

Kebun karet memiliki BV berkisar antara 0,83-1,03 $\mathrm{g} / \mathrm{cm}^{3}$ yang berada pada kriteria sedang. Nilai BV meningkat seiring dengan bertambahnya kelerengan lahan. Hal ini disebabkan karena rendahnya bahan organik tanah yang juga mengalami penurunan seiring bertambahnya kelerengan lahan. Kandungan bahan organik tanah akan mempengaruhi BV tanah. Pemberian bahan organik ke dalam tanah dapat meningkatkan jumlah ruang pori tanah dan membentuk struktur tanah yang remah sehingga akan menurunkan berat volume tanah (Saputra et al., 2018).

Lahan sawah memiliki nilai BV tanah yang bervariasi tetapi masih dalam kriteria sedang, yaitu $0,87-0,94 \mathrm{~g} / \mathrm{cm}^{3}$. Perbedaan nilai $\mathrm{BV}$ dipengaruhi oleh kandungan bahan organik tanah. Semakin tinggi kandungan bahan organik tanah maka nilai BV akan semakin 
rendah. Nilai BV pada lahan sawah juga dipengaruhi oleh pengolahan tanah. Proses pelumpuran menyebabkan agregat tanah hancur menjadi lumpur. Setelah proses pelumpuran selesai, air genangan yang tenang akan mengendapkan partikel tanah. Partikel tanah yang mengendap akan mengalami stratifikasi yang akan menyebabkan daya kohesi antar partikel semakin kuat sehingga tanah menjadi lebih padat (Hardjowigeno dan Rayes, 2005).

\section{Stok Karbon Tanah}

Berdasarkan perhitungan stok karbon tanah pada daerah penelitian berkisar 0,19-0,41 $\mathrm{kg} / \mathrm{m}^{2}$ (Tabel 3). Hal ini dipengaruhi oleh penggunaan lahan yang mempengaruhi kandungan C-organik tanah, di mana pada wilayah dengan tutupan vegetasi yang rapat memiliki kandungan $\mathrm{C}$-organik yang tinggi. Stok karbon pada berbagai tipe penggunaan lahan selain dipengaruhi oleh faktor alami yaitu curah hujan, topografi, dan kondisi vegetasi juga dipengaruhi oleh intensitas pengolahan tanah dan pemupukan yang secara langsung maupun tidak langsung akan mempengaruhi sifat tanah termasuk kandungan C-organik dan kerapatan lindak (Edwin, 2016).

Kebun campuran memiliki stok karbon tanah bervariasi yang berkisar $0,19-2,17 \mathrm{~kg} / \mathrm{m}^{2}$. Hal ini disebabkan oleh kandungan C-organik tanah, semakin rendah kandungan C-organik tanah akan menyebabkan stok karbon tanah juga rendah.

Tabel 3. Jumlah stok karbon tanah di Nagari Padang Laweh

\begin{tabular}{llclcccc}
\hline $\begin{array}{c}\text { No. } \\
\text { SL }\end{array}$ & \multicolumn{1}{c}{ Ordo } \\
Tanah & $\begin{array}{c}\text { Kelas } \\
(\%)\end{array}$ & $\begin{array}{c}\text { Penggunaan } \\
\text { Lahan }\end{array}$ & $\begin{array}{c}\text { Kedalaman } \\
(\mathrm{cm})\end{array}$ & $\begin{array}{c}\text { C-organik } \\
(\%)\end{array}$ & $\begin{array}{c}\text { BV } \\
\left(\mathrm{g} / \mathrm{cm}^{3}\right)\end{array}$ & $\begin{array}{c}\text { Stok } \\
\text { karbon } \\
\left(\mathrm{kg} / \mathrm{m}^{2}\right)\end{array}$ \\
\hline 1 & Inceptisols & $0-8$ & Kebun Campuran & $0-20$ & 1.03 & 0.92 & 0.19 \\
2 & Inceptisols & $8-15$ & Kebun Campuran & $0-20$ & 1.77 & 0.86 & 0.30 \\
3 & Ultisols & $8-15$ & Kebun Campuran & $0-20$ & 1.94 & 0.92 & 0.36 \\
4 & Inceptisols & $8-15$ & Sawah & $0-20$ & 1.97 & 0.87 & 0.34 \\
5 & Ultisols & $8-15$ & Sawah & $0-20$ & 1.92 & 0.90 & 0.35 \\
6 & Ultisols & $0-8$ & Sawah & $0-20$ & 1.40 & 0.92 & 0.26 \\
7 & Inceptisols & $0-8$ & Sawah & $0-20$ & 1.02 & 0.94 & 0.19 \\
8 & Ultisols & $0-8$ & Kebun Campuran & $0-20$ & 2.17 & 0.90 & 0.39 \\
9 & Inceptisols & $15-25$ & Kebun Campuran & $0-20$ & 1.61 & 0.91 & 0.29 \\
10 & Inceptisols & $8-15$ & Kebun Karet & $0-20$ & 2.49 & 0.83 & 0.41 \\
11 & Inceptisols & $15-25$ & Kebun Karet & $0-20$ & 2.02 & 0.89 & 0.36 \\
12 & Inceptisols & $25-40$ & Kebun Karet & $0-20$ & 1.23 & 0.91 & 0.22 \\
13 & Ultisols & $>40$ & Kebun Karet & $0-20$ & 1.00 & 1.05 & 0.21 \\
14 & Inceptisols & $15-25$ & Sawah & $0-20$ & 1.61 & 0.93 & 0.30 \\
\hline
\end{tabular}

Lahan sawah memiliki stok karbon berkisar 0,19-0,34 $\mathrm{kg} / \mathrm{m}^{2}$. Perbedaan stok karbon ini disebabkan karena perbedaan nilai BV tanah, di mana lahan sawah yang memiliki nilai BV tanah rendah akan memiliki stok karbon lebih tinggi. Tanah dengan BV rendah biasanya memiliki kandungan bahan organik tanah tinggi, karena bahan organik akan meningkatkan ruang pori tanah dan membentuk struktur tanah yang remah sehingga menurunkan BV tanah. Perbedaan stok karbon pada lahan sawah juga disebabkan oleh manajemen lahan yang dilakukan oleh petani, pada lahan sawah tidak ada pengembalian bahan organik ke lahan, karena jerami sisa panen dikumpulkan di satu tempat kemudian dibakar hingga menjadi abu. Hal ini juga yang menyebabkan kandungan C-organik tanah sawah rendah yang selanjutnya 
menyebabkan stok karbon tanahnya juga rendah.

Penggunaan lahan kebun karet memiliki stok karbon berkisar 0,21-0,41 kg/m². Kandungan stok karbon menurun dengan meningkatnya kelerengan lahan. Hal ini terjadi karena curah hujan pada daerah penelitian yang tinggi dan fluktuasi iklim tropis menyebabkan pelapukan bahan organik tanah berlangsung cepat yang berdampak terhadap stok karbon tanah. Kandungan C-organik tanah pada kebun karet dipengaruhi oleh faktor kelerengan lahan dan intensitas pengolahan tanah yang relatif rendah (Edwin, 2016).

\section{Hubungan Stok karbon dan Suhu permukaan Tanah}

Berdasarkan Gambar 2, dapat dilihat bahwa suhu permukaan tanah tidak memberikan pengaruh yang besar terhadap stok karbon tanah. Hal ini terjadi karena nilai R2 hanya $0,0001(0,1 \%)$, yang berarti sumbangan pengaruh suhu permukaan terhadap stok karbon tanah hanya sebesar $0,1 \%$, sedangkan sisanya sebesar $99 \%$ dipengaruhi oleh faktor lain yang tidak dimasukkan dalam model penelitian ini. Faktor iklim termasuk suhu permukaan tanah memang menjadi salah satu faktor yang menentukan stok karbon tanah, akan tetapi faktor lain yang mempengaruhi stok karbon tanah adalah curah hujan, kerapatan vegetasi, topografi, praktik manajemen lahan, dan pemberian bahan organik.

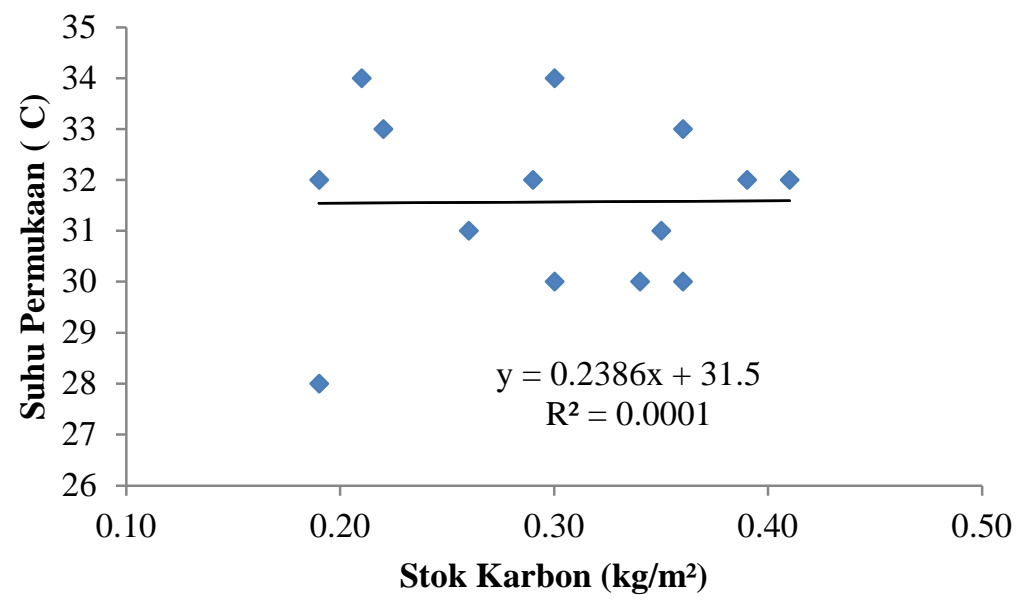

Gambar 2. Hubungan stok karbon tanah dan suhu permukaan tanah
Secara umum, perubahan suhu secara signifikan akan mengubah aktivitas enzim tanah yang akan menyebabkan meningkatnya laju dekomposisi bahan organik tanah dan fraksi labil C-organik tanah (Qi et al., 2016). Akan tetapi, pemanasan iklim jangka pendek tidak akan mempengaruhi stok C-organik tanah (Guan et al., 2018).

Pengolahan tanah menjadi faktor yang sangat penting terhadap stok karbon tanah. persiapan lahan yang intensif akan memecah agregat tanah yang membuat $\mathrm{C}$ yang tersimpan di dalam agregat tanah menjadi terlepas. Pengolahan tanah menciptakan kondisi tanah yang lebih baik untuk aktivitas mikroba tanah, yang mendukung kontak antara mikroba tanah dengan residu tanaman, dan juga meningkatkan aerasi profil tanah (Martin et al., 2019).

\section{KESIMPULAN}

Berdasarkan penelitian yang telah dilaksanakan, dapat disimpulkan bahwa:

1. Stok karbon tanah tertinggi terdapat pada penggunaan lahan kebun karet dan menurun dengan bertambahnya kelerengan lahan. Stok karbon pada lahan sawah dipengaruhi oleh tidak adanya 
pengembalian sisa panen dan tidak adanya pemberian pupuk organik.

2. Suhu permukaan tidak memberikan pengaruh yang signifikan terhadap stok karbon tanah, karena stok karbon tanah tidak terpengaruh terhadap kenaikan suhu permukaan tanah.

\section{DAFTAR PUSTAKA}

Balai Penelitian Tanah. 2012. Petunjuk Teknis Analisis Kimia Tanah, Tanaman, Air, dan Pupuk. 234 halaman.

BPS Sijunjung. 2018. Kecamatan Koto VII dalam Angka 2018. Muaro Sijunjung. 125 halaman.

Behtari, B., Jafarian, Z., Alikhani, H. 2019. Temperature Sensitivity of Soil Organic Matter Decomposition in Response to Land Management in Semi-arid Rangeland of Iran. Catena 179 (2019) 210-219.

DOI: http://dx.doi.org/10.1016/j.catena.2019.0 3.043

Chan, K.Y. 2001. Soil Particulate Organic Carbon Under Different Land Use and Management. Soil Use and Management 217-221.

DOI: http://dx.doi.org/10.1079/SUM200180

Edwin, M. 2016. Penilaian Stok Karbon Tanah Organik pada Beberapa Tipe Penggunaan Lahan di Kutai Timur, Kalimantan Timur. Jurnal AGRIFOR Vol. XV No. 2 (2016)

Ermadani, Hermansyah, Yulnafatmawita, Syarif, A. 2018. Dynamic of Soil Organic Carbon Fraction Under Different Land Management in Wet Tropical Areas. Jurnal Solum Vol. 15 No. http://dx.doi.org/10.25077/j.solum.15.1.2 6-39.2018
Fathizad, H., Tazeh, M., Kalantari, S., Shojaei, S. 2017. the Investigation of spatiotmporal Variations of Land Surface Temperature Based on Land Use Change Using NDVI in Southwest of Iran. Journal of Africa Earth Science 134 (2017)

249-256. http://dx.doi.org/10.1016/j.jafrearsci.201 7.06.007

Guan, S., An, N., Zong, N., He, Y., Shi, P., Zhang, J., He, N. 2018. Climate Warming Impact on Soil Organic Carbon Fractions and Aggregate Stability in a Tibetan Alpine Meadow. Soil Biology and Biochemistry 116 (2018) 224-236. http://dx.doi.org/10.1016/j.soilbio.2017.1 $\underline{0.011}$

Hanafiah, K.A. 2005. Dasar-dasar Ilmu Tanah. Jakarta. Raja Grafindo Persada. 360 halaman.

Hardjowigeno, S. dan L. Rayes. 2005. Tanah Sawah, Karakteristik, Kondisi, dan Permasalahan Tanah Sawah di Indonesia. Bayumedia. Malang. 205 halaman.

Husnain. 2010. Kehilangan Unsur Hara Akibat Pembakaran Jerami Padi dan Potensi Pencemaran Lingkungan. Prosiding seminar nasional sumber daya lahan pertanian. Balai Penelitian Tanah.

Iskandar, B. 2014. Dinamika Litterfall dan Kecepatan Dekomposisi Serasah pada Agroekosistem Perkebunan Karet di Kabupaten Dharmasraya. Skripsi. Universitas Andalas. Padang. 54 halaman.

Kassa, H., Dondeyne, S., Poesen, J., Frankl, A., Nyssen, J. 2017. Impact of Deforestation on Soil Fertility, Soil Carbon and Nitogen Stock: the Case of the Gacheb Catchment in the White Nile Basin, Ethiopia. Agriculture, Ecosystem and 
Environmental $247 \quad$ (2017) 273-282. http://dx.doi.org/10.1016/j.agee.2017.06. $\underline{034}$

Khandelwal, S., Goyal, R., Kaul, N., Mathew, A. 2018. Assessment of Land Surface Temperature Variation due to Change in Elevation of Area Surrounding Jaipur India. The Egyptian Journal of Remote Sensing and Space Science 21 (2018) 8794.

http://dx.doi.org/10.1016/j.ejrs.2017.01.0 $\underline{05}$

Krauss, M., Ruser, R., Muller, T., Hansen, S., Mader, P., Gattinger, A. 2017. Impact of Reduced Tillage on Greenhouse Gass Emissions and Soil Carbon Stock in an Organic Grass-clover Ley - Winter Wheat Cropping Sequence. Agriculture, Ecosystem and Environment 239 (2017) 324-333.

http://dx.doi.org/10.1016/j.agee.2017.01. 029

Martin, J.A.R., Alvaro-Fuentes, J., Gabriel, J.L., Gutierrez, C., Nanos, N., Escuer, M., Ramos-Miras, J.J., Gil, C., MartinLammerding, D., Boluda, R. 2019. Soil Organic Carbon Stock on the Majorca Island: Temporal Change in Agricultural Soil Over the Last 10 Years. Catena 181 (2019) 104087.

DOI: $\underline{10.1016 / j . c a t e n a .2019 .104087}$

Nurida, N.L., Haridjaja, O., Arsyad, S., Sudarsono, Kurnia, U., Djajakirana, G. 2007. Perubahan Fraksi Bahan Organik Tanah Akibat Perbedaan Cara Pemberian dan Sumber Bahan Organik pada Ultisol Jasinga. Jurnal Tanah dan Iklim No. 26 (2007).

Pires, C.V., Schaefer, C.E.R.G., Hashigushi, A.K., Thomazini, A., Filho, E.I.F., Mendonca, E.S. 2017. Soil Organic
Carbon and Nitrogen Polls Drive Soil C$\mathrm{CO}_{2}$ Emissions from Selected Soil in Maritime Antartica. Science of the Total Environment 596-597 (2017) 124-135. http://dx.doi.org/10.1016/j.scitotenv.201

7.03.144

Puturuhu, F. 2015. Geologi Ilmu Tanah dan Sumber Daya Lahan. Yogyakarta. Penerbit Ombak. 102 halaman.

Qi, R., Li, J., Lin, Z., Li, Z., Li, Y., Yang, X., Zhang, J., Zhao, B. 2016. Temperature Effects on Soil Organic Carbon, Soil Labile Carbon Fraction, and Soil Enzyme Activities Under Long-term Fertilization Regimes. Applied Soil Ecology $102 \quad$ (2016) 36-45. http://dx.doi.org/10.1016/j.apsoil.2016.0 2.004

Qin, Z. and Karnieli, A. 1999. Progress in the Remote Sensing of Land Surface Temperature and Ground Emissivity Using NOAA-AVHRR data. Int. J. Remote Sensing vol. 12, 2367-2393. DOI: $10.1080 / 014311699212074$

Saputra, D.D., Putrantyo, A.R., Kusuma, Z. 2018. Hubungan Karbon Organik Tanah dengan Berat Isi, Porositas dan Laju Infiltrasi pada Perkebunan Salak di Kecamatan Purwosari, Kabupaten Pasuruan. Jurnal Tanah dan Sumberdaya Lahan Vol. 5 No. 1 : 647-654, 2018

Smith, P., Fang, C., Dawson, J.J.C., Moncrieff, J.B. 2008. Impact of Global Warming on Soil Organic Carbon. Advance in Agronomy volume 97. DOI: 10.1016/S0065-2113(07)00001-6

Strosser, E. 2010. Methods for Determination of Labile Soil Organic Matter: An Overview. Journal of Agrobiology 27(2): 49-60. DOI: 10.2478/s10146-009-0008-x 